\title{
Ephippia of the Daphniidae (Branchiopoda: Cladocera) in Late Caenozoic deposits: untapped source of information for palaeoenvironment reconstructions in the Northern Holarctic
}

\author{
A.A. Kotov ${ }^{1,2^{\star}}$, S.A. Kuzmina ${ }^{3}$, L.A. Frolova ${ }^{2}$, A.A. Zharov ${ }^{3,4}$, \\ A.N. Neretina ${ }^{1}$, N.N. Smirnov ${ }^{1}$ \\ ${ }^{1}$ Laboratory for Ecology of Aquatic Communities and Invasions, A.N. Severtsov Institute of Ecology \\ and Evolution, Leninsky Prospect 33, Moscow 119071, Russia. \\ ${ }^{2}$ Laboratory of Palaeoclimatology, Palaeoecology, Palaeomagnetism, Kazan Federal University, \\ Kremlevskaya Street 18, Kazan 420008, Russia. \\ ${ }^{3}$ Laboratory of Arthropods, Borissiak Palaeontological Institute, Profsoyuznaya Str. 123, Moscow, \\ 117997, Russia. \\ ${ }^{4}$ Laboratory of Genome Evolution and Speciation Mechanisms, N.K. Koltzov Institute of Develop- \\ mental Biology, Vavilova 26, Moscow, 119334, Russia. \\ *Corresponding author: alexey-a-kotov@yandex.ru
}

\begin{abstract}
Cladoceran remains, mostly ephippia of the Daphniidae (Crustacea: Branchiopoda), are widespread in the permafrost deposits of Northern Eurasia. We may expect their presence in all types of Quaternary deposits from all regions of the permafrost zone. Cladoceran remains could be used for reconstruction of the past environment, climate and condition of the sediment accumulation, and cladoceran analysis could potentially be widely applied in Quaternary ecology. Moreover, resting eggs of Daphnia and other cladocerans could be good material for DNA studies and even hatching of specimens. Therefore, the ephippia could potentially be an important source of quantitative information for palaeoecological reconstructions. But for such efforts they need to be studied specially instead of as a byproduct of palaeoentomological or palaeobotanical studies. Moreover, special studies of recent taxa aiming to elucidate their identification based on ephippia are needed urgently. The impetus for this paper is to attract the attention of the Quaternary science community to ephippia as a new source of information about the past of inland waters.

How to cite this article: Kotov A.A., Kuzmina S.A., Frolova L.A., Zharov A.A., Neretina A.N., Smirnov N.N. 2019. Ephippia of the Daphniidae (Branchiopoda: Cladocera) in Late Caenozoic deposits: untapped source of information for palaeoenvironment reconstructions in the Northern Holarctic // Invert. Zool. Vol.16. No.2. P.183-199. doi: 10.15298/ invertzool.16.2.06
\end{abstract}

KEY WORDS: Daphnia, Cladocera, Anomopoda, palaeoenvironment, palaeoecology, Holocene, Pleistocene, Pliocene. 


\title{
Эфиппиумы Daphniidae (Branchiopoda: Cladocera) в позднекайнозойских отложениях: неиспользуемый источник информации о палеообстановках Северной Голарктики
}

\author{
А.А. Котов ${ }^{1,2^{*}}$, С.А. Кузьмина ${ }^{3}$ Л.А. Фролова², А.А. Жаров ${ }^{3,4}$, \\ А.Н. Неретина ${ }^{1}$, Н.Н. Смирнов ${ }^{1}$

\begin{abstract}
1 Лаборатория экологии водных сообществ и инвазий, Институт проблем экологии и эволюичи им. А.Н. Севериова РАН, Ленинский проспект 33, Москва 119071, Россия.

2 Лаборатория палеоклиматологии,палеоэкологии и палеомагнетизма, Казанский (Приволжский) федеральный университет, ул. Кремлевская 18, Казань 420008, Республика Татарстан, Россия.

${ }^{3}$ Лаборатория артропод Палеонтологический институт им. А.А. Борисяка, ул. Профсоюзная 123, Москва, 117997, Россия.

${ }^{4}$ Лаборатория эволючии генома и механизмов видообразования, Институт биологии развития им. Н.К. Кольчова, ул. Вавилова 26, Москва, 119334, Россия.

*Автор для переписки: alexey-a-kotov@yandex.ru
\end{abstract}

PЕЗЮМЕ: Остатки ветвистоусых ракообразных (Crustacea: Branchiopoda), в первую очередь, эфиппиумы Daphniidae, широко представлены в многолетнемерзлых отложениях Северной Голарктики. Можно ожидать, что они могут быть найдены во всех типах четвертичных отложений и во всех регионах зоны вечной мерзлоты. Остатки Cladocera могут быть использованы как источник информации об окружающей среде прошлого, климатических условиях и особенностях осадконакопления, кладоцерный анализ может широко использоваться в исследованиях по четвертичной экологии. Кроме того, покоящиеся яйца Daphnia и других ветвистоусых ракообразных могут быть хорошим источником материала для исследований ДНК и даже для выведения особей из покоящихся яиц. Эфиппиумы потенциально могут быть надежным источником количественной информации для палеоэкологических реконструкций. Однако для подобных исследований они должны изучаться специально, а не как побочный продукт палеоэнтомологических или палеоботанических работ. Мало того, необходимо приложить специальные усилия для выработки ключей для идентификации современных видов по эфиппиумам. Основная идея публикации данного сообщения - привлечь внимание сообщества ученых, изучающих четвертичный период, к эфиппиумам как новому источнику информации о прошлом водоемов.

Как цитировать эту статью: Kotov A.A., Kuzmina S.A., Frolova L.A., Zharov A.A., Neretina A.N., Smirnov N.N. 2019. Ephippia of the Daphniidae (Branchiopoda: Cladocera) in Late Caenozoic deposits: untapped source of information for palaeoenvironment reconstructions in the Northern Holarctic // Invert. Zool. Vol.16. No.2. P.183-199. doi: 10.15298/invertzool.16.2.06

КЛЮЧЕВЫЕ СЛОВА: Daphnia, Cladocera, Anomopoda, палеообстановка, палеоэкология, голоцен, плейстоцен, плиоцен. 


\section{Introduction}

Since the pioneering works of the beginning of $20^{\text {th }}$ century (Voronkov, Troitsky, 1907; Rossolimo, 1927), subfossil remains of Cladocera (Crustacea: Branchiopoda) have been found in Quaternary lake deposits by many investigators (Deevey, 1942; Frey, 1958, 1964, 1986; Kadota, 1973; Smirnov, 1984; Duigan, Birks, 2000; Cromer et al., 2006; Rautio, 2007; Frolova et al., 2017). Cladoceran analysis of lake sediment cores is used for reconstruction of changes in some lake features such as depth, water transparency, and for revealing water body acidification and eutrophication (Alhonen, 1970; Hann, Karrow, 1984, 1993; SarmajaKorjonen, 2001, 2003, 2004; Rautio, 2007; Frolova, 2009; Smirnov, 2010; Frolova et al., 2014; Ohtsuki et al., 2015; Frolova et al., 2017; Ulrich et al., 2017).

A very important component of cladoceran remains in Quaternary sediments is so-called 'ephippia', moulted exuviae of gamogenetic females, modified in a special manner, enclosing resting eggs, protecting them from a harmful influence of the environment and being the main dispersal phase of ontogenesis (Pietrzak, Slusarczyk, 2006; Kotov, 2013). Ephippium presence is a diagnostic trait of the cladoceran order Anomopoda Sars, 1865, while representatives of all other recent cladoceran orders deposit their resting eggs without ephippia (Fryer, 1995; Kotov, 2013). Ephippia are the most common remains of the family Daphniidae Straus, 1820 while other body parts are only rarely preserved in Holocene (Frey, 1991; Szeroczyńska, Zawisza, 2005) or Pleistocene (Cromer et al., 2006) sediments.

Cladocera is a group of Palaeozoic origin (Fryer, 1991, 1995; Sacherová, Hebert, 2003; Kotov, 2013; Van Damme, Kotov, 2016). However, the oldest anomopod ephippia known to date are from the exact Jurassic-Cretaceaus boundary (145 Mya), and they could be already attributed to daphniid genera from two recent subgenera, Simocephalus Schödler, 1858 (family Daphniidae) and Moina Baird, 1850 (family Moinidae Goulden, 1968), existing at present
(Smirnov, 1992; Kotov, Taylor, 2011). Daphniid ephippia were also found in several Cretaceous localities (Fryer, 1991; Kotov, 2009; YanBin, Di-Ying, 2008; Hegna, Kotov, 2016).

Caenozoic ephippia are known since the pioneering work of Heydon (1862), but in general, records of Palaeogene and early Neogene cladocerans are relatively rare in the palaeontological literature (Dickinson, Swain, 1967; Goulden, 1968; Xing-rong, Li Ying-pei, 1987; Lea et al., 1991; Lutz, 1991; Wappler et al., 2014; Kotov, Wappler, 2015) as compared with a great number of the Late Holocene records. Some localities are found to be especially remarkable, for example, Richter \& Wedman (2005) described the ephippia of presumably "recent" species Moina macrocopa (Straus, 1820), Daphnia pulex De Geer, 1778 and Daphnia magna Straus, 1820) from Eocene Lake Messel, although their identifications seem to be not well-justified.

Ephippia and other cladoceran remains in Pliocene - Pleistocene - Earlier Holocene strata have been reported in papers written mainly by entomologists or botanists (Bennike, Böcher, 1990, 1992; Matthews, Telka, 1997; Lemdahl, 2000; Zimmermann, Lavoie, 2001; Kienast et al., 2001, 2011; Oksanen et al., 2003; Woodward, Shulmeister, 2007; Moldovan et al., 2011; Cañellas-Boltà et al., 2015; Gracheva et al., 2015). But even through such investigations are relatively numerous, these records occur remarkably rarely when compared with those for upper Holocene deposits. Quaternary ephippia were almost never described in detail. Resting eggs and ephippia, mainly of daphniid Cladocera, have been studied mostly from Holocene deposits (see reviews by Brendonck, De Meester, 2003, Amsinck et. al., 2007) but not extensively and they rarely are used for any palaeoenvironmental reconstructions (Ulrich et al., 2017).

The aim of this communication is to attract the attention of palaeoecologists to a possible significance of Daphniidae ephippia for Pleistocene palaeoenvironmental reconstructions following the analogous works on the Late Holocene. 


\section{Results and Discussion}

Notes on the taxon identification based on ephippia

Ephippia of Daphnia are common in the Quaternary deposits (Table). They have a char- acteristic external appearance, and mostly bear two eggs (with exception of few species with a single egg, which are absent in the Northern Holarctic and not discussed here) (Glagolev, 1983; Benzie, 2005; Mergeay et al., 2005; Kotov, 2013). Daphnia ephippia characters are usable for the determination of two main sub-

Table. Original material studied here.

Таблица. Оригинальный материал, изученный авторами.

\begin{tabular}{|c|c|c|}
\hline No & Section name and description & $\begin{array}{l}\text { Taxa revealed } \\
\text { (ephippia) }\end{array}$ \\
\hline 1 & $\begin{array}{l}\text { Section Sabler-1. Cape Sabler Peninsula }\left(74^{\circ} 33^{\prime} \mathrm{N}, 100^{\circ} 32^{\prime} \mathrm{E}\right) \\
\text { of Lake Taimyr, Taimyr Peninsula, Russia (described by } \\
\text { Dereviagin et al., } 1997 \text { and Kienast et al., 2001). The samples } \\
\text { from different depth }(0.7-0.8,13.2,20,25.2 \mathrm{~m}) \text { were studies by } \\
\text { F. Kienast. The oldest ephippia photographed here (Fig. } 1 \mathrm{~A}) \\
\text { were found at depth of } 25.2 \mathrm{~m} \text {, they are about } 30.000 \text { years old } \\
\text { (the sample from } 25 \mathrm{~m} \text { was dated as } 29.960 \pm 790 \mathrm{yr} \mathrm{BP}) \text {. }\end{array}$ & $\begin{array}{l}\text { Daphnia (Daphnia) } \\
\text { cf. pulex }\end{array}$ \\
\hline 2 & $\begin{array}{l}\text { Samoylov Island. Samoylov Island, the Lena River delta, } \\
\text { North Yakutia }\left(72^{\circ} 22^{\prime} 10^{\prime \prime} \mathrm{N} 126^{\circ} 29^{\prime} 58^{\prime \prime} \mathrm{E}\right) \text { The samples SAM- } \\
\text { 1-B1, SAM-1-B2, SAM-1-B1, were taken by S.K. from } \\
\text { Holocene river terrace (less than } 5000 \text { yr BP). }\end{array}$ & $\begin{array}{l}\text { Daphnia (Daphnia) } \\
\text { cf. longispina }\end{array}$ \\
\hline 3 & $\begin{array}{l}\text { Cape Letyatkin. Borehole }\left(69^{\circ} 42^{\prime} \mathrm{N} 163^{\circ} 18^{\prime} \mathrm{E}\right) \text {, Cape } \\
\text { Letyatkin, East Siberian Sea } 50 \mathrm{~km} \text { E of the Kolyma River } \\
\text { mouth. Sample } 111 / 2 \text { (Pliocene?) was studied by S. Kiselev. }\end{array}$ & $\begin{array}{l}\text { Daphnia (Daphnia) } \\
\text { cf. pulex }\end{array}$ \\
\hline 4 & $\begin{array}{l}\text { Titaluk. River Titaluk }\left(69^{\circ} 25^{\prime} \mathrm{N}, 155^{\circ} 9^{\prime} \mathrm{W}\right) \text {, North Slope, } \\
\text { Alaska, U.S.A. The sample T03-B12 has been taken from a } \\
\text { boggy-lake deposit Early Holocene (about } 9.000 \text { yr BP) } \\
\text { "Populus beds". The sample comes from a sandy peat unit with } \\
\text { abundant remains of leaves and a well preserved water beetle } \\
\text { fauna. Section has been studied by P. Matheus, A. Sher and } \\
\text { S.K. (Kuzmina et al., 2019). }\end{array}$ & $\begin{array}{l}\text { Daphnia (Daphnia) } \\
\text { cf. pulex; Daphnia } \\
\text { (Daphnia) sp. from } \\
\text { longispina-group; } \\
\text { Simocephalus sp. }\end{array}$ \\
\hline 5 & $\begin{array}{l}\text { Palisades. Yukon River, } 55 \mathrm{~km} \text { downstream from Tanana } \\
\text { village }\left(65^{\circ} 06^{\prime} \mathrm{N}, 153^{\circ} 15^{\prime} \mathrm{W}\right) \text {, Alaska, U.S.A. Ephippia are } \\
\text { numerous in samples AL-4-05 B15, AL-4-05 B16, AL-4-05 } \\
\text { B20A and AL-4-05 B25. This section has been described by } \\
\text { Matheus et al. (2003) and studied in } 2005 \text { by D. Froese, A. } \\
\text { Reyes and S. Kuzmina (inpublished). The samples come from } \\
\text { two units: AL-4-05 B15 and B16 from the lower, Middle } \\
\text { Pleistocene peat bed; B20A and B25 from the Late Pleistocene } \\
\text { (last interglaciation). }\end{array}$ & $\begin{array}{l}\text { Daphnia (Daphnia) } \\
\text { cf. pulex }\end{array}$ \\
\hline 6 & $\begin{array}{l}\text { Chester Bluff. The right Yukon River bank }\left(64^{\circ} 28^{\prime} \mathrm{N} \text {, }\right. \\
\left.142^{\circ} 43^{\prime} \mathrm{W}\right) \text { about } 40 \mathrm{~km} \text { downstream from Eagle, in east-central } \\
\text { Alaska, U.S.A. Ephippia are very numerous in the samples AL- } \\
5-05 \text { B27, AL-5-05 B27A and AL-5-05 B37 (an interglacial } \\
\text { bed of the Middle Pleistocene) The section has been described } \\
\text { by Froese et al. (2003); the samples were collected by S.K in } \\
2005 .\end{array}$ & $\begin{array}{l}\text { Daphnia (Daphnia) } \\
\text { sp. (pulex-group) }\end{array}$ \\
\hline
\end{tabular}


Table (continued). Таблица (продолжение).

\begin{tabular}{|c|c|c|}
\hline No & Section name and description & $\begin{array}{l}\text { Taxa revealed } \\
\text { (ephippia) }\end{array}$ \\
\hline 7 & 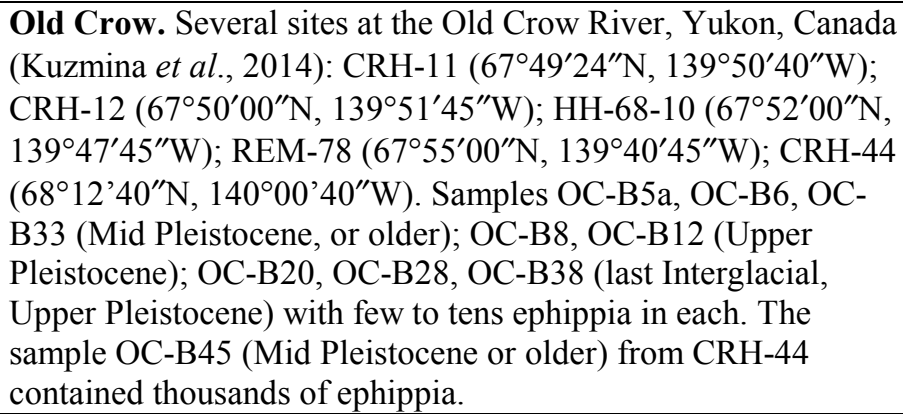 & $\begin{array}{l}\text { Daphnia (Daphnia) } \\
\text { sp. (longispina- } \\
\text { group); } \\
\text { Simocephalus sp. } 1 \\
\text { \& sp. } 2 \text {. }\end{array}$ \\
\hline 8 & $\begin{array}{l}\text { Allan Creek. }\left(60^{\circ} 30^{\prime} \mathrm{N}, 129^{\circ} 44^{\prime} \mathrm{W}\right) \text { Liard Lowland of Yukon, } \\
\text { Canada, probably Mio-Pliocene gravels, sample BJ-17 LR-21 } \\
\text { was taken by B. Jensen in } 2017 \text {. }\end{array}$ & $\begin{array}{l}\text { Daphnia (Daphnia) } \\
\text { sp. (pulex-group) }\end{array}$ \\
\hline 9 & $\begin{array}{l}\text { Tom Creek. }\left(60^{\circ} 12^{\prime} \mathrm{N}, 129^{\circ} 2^{\prime} \mathrm{W}\right) \text { Liard Lowland of Yukon, } \\
\text { Canada. Organic-rich silts underlying LGM till, Late } \\
\text { Pleistocene, sample AVR-17TC-9a was taken by A. Reyes in } \\
2017 .\end{array}$ & $\begin{array}{l}\text { Daphnia (Daphnia) } \\
\text { sp. (pulex-group) }\end{array}$ \\
\hline 10 & $\begin{array}{l}\text { Alberta, pit No } 48 .\left(53^{\circ} 38^{\prime} 30^{\prime \prime} \mathrm{N}, 113^{\circ} 17^{\prime} 0^{\prime \prime} \mathrm{W}\right) \text { Inland } \\
\text { Aggregates Pit } 48 \text {, Villeneuve, approximately } 10 \text { kilometres } \\
\text { northwest of Edmonton, Alberta, Canada, Late Pleistocene. } \\
\text { Sample was taken by J. Seal. }\end{array}$ & $\begin{array}{l}\text { Daphnia } \\
\text { (Ctenodaphnia) } \\
\text { magna; Daphnia } \\
\text { (Daphnia) sp. from } \\
\text { longispina-group }\end{array}$ \\
\hline
\end{tabular}

genera, because the egg axes are perpendicular (or sub-perpendicular) to the dorsal ephippium margin in the subgenus Daphnia s.str., while in the subgenus D. (Ctenodaphnia) Dybowski et Grochowski, 1895 these axes are aslant or even parallel to the dorsal margin (Benzie, 2005; Kotov, Taylor, 2011).

Glagolev (1983) concluded that the shape and sculpture of Daphnia ephippia have a limited value for inter-subgeneric taxonomy, although sometimes are helpful for discrimination of some close species, i.e. D. galeata and $D$. cucullata. Subsequent investigators were more successful in findings of diagnostic traits of the ephippia. For example, Mergeay et al. (2005) proposed a key for determination of the ephippia of African Daphnia species based on their general shape. It is accepted now, that presence of relatively large spinules on the dorsal plate is a character of $D$. pulex species group (Fig. 1) in contrast to D. longispina group with almost smooth dorsal margin (Fig. 2) (Benzie, 2005). But species discrimination within the latter two large groups using ephippia is very difficult, especially keeping in mind that recent taxonomy of these groups is confusing and several cryptic species co-exist in the Palaearctic and Nearctic within both the pulex and longispina groups (Benzie, 2005; Petrusek et al., 2008; Crease et al., 2012; Kotov, 2015). Only some very preliminary ideas on the species differences within the pulex-group are formulated (i.e., by Vanderkerkhove et al., 2004; Mergeay et al., 2005), for example, it is known that a posterior ephippium tapering is characteristic for $D$. pulex in contrast to D. obtusa (Glagolev, 1983; Mergeay et al., 2005).

More promising are efforts to elaborate a key for identification of Daphnia (Ctenodaphnia) ephippia, although the authors take into consideration predominantly a general shape of the ephippium, ignoring its sculpture (Mergeay 

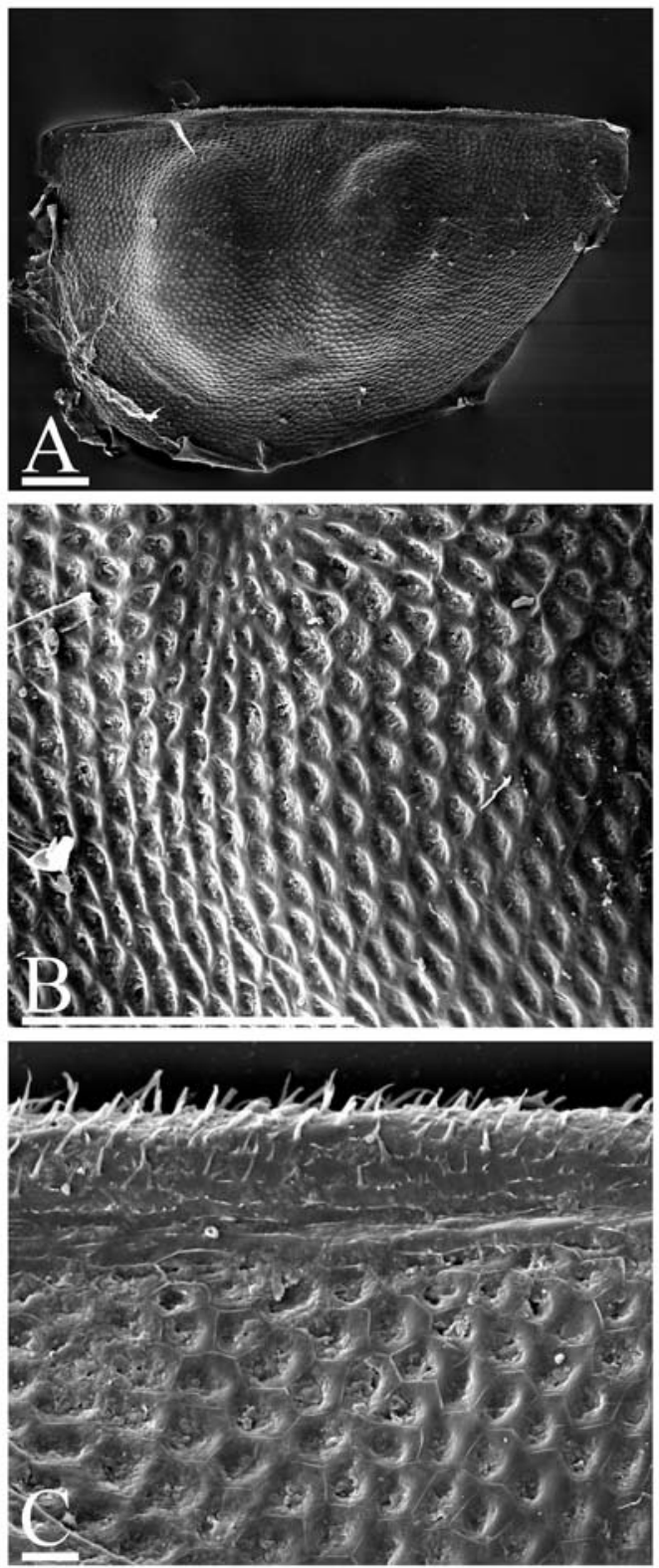
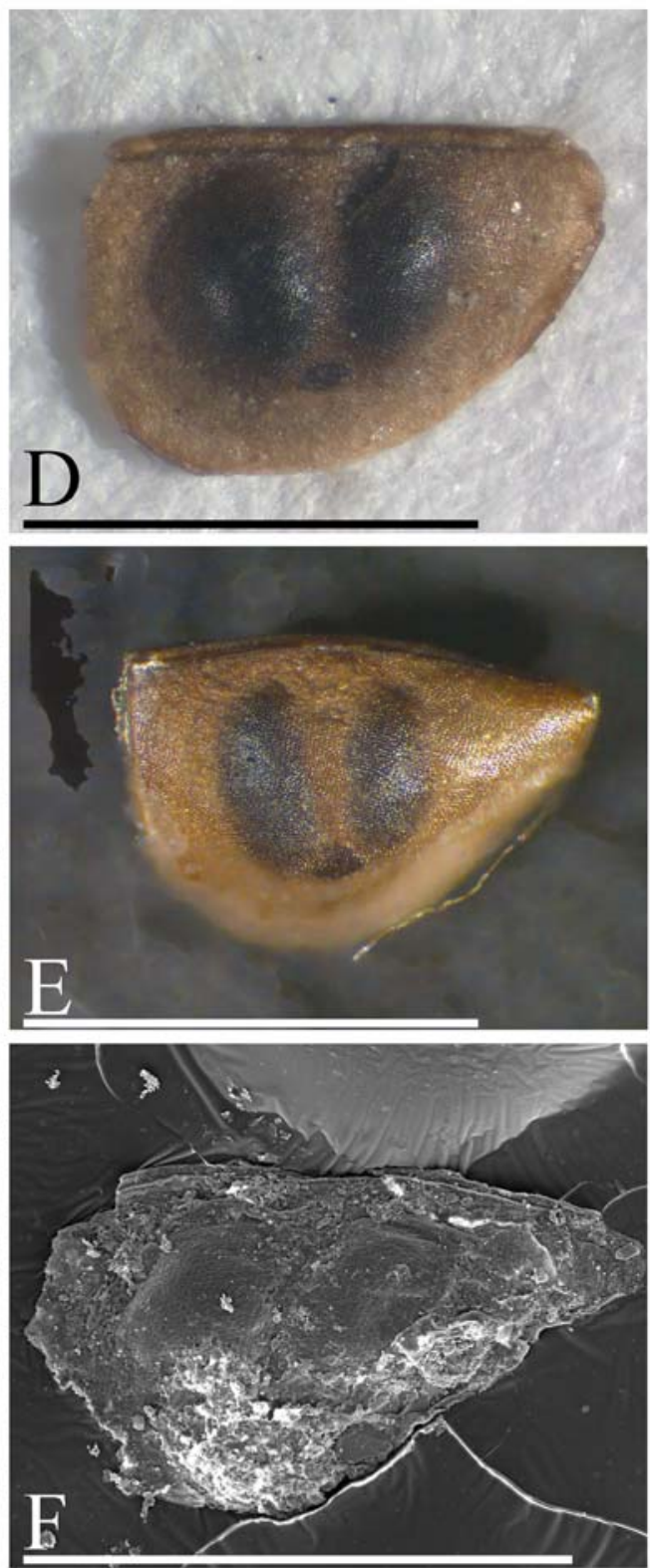

Fig. 1. Fossil ephippia of Daphnia (Daphnia) pulex group.

A-C - Cape Sabler, Taimyr, Russian Federation, sample from depth of $25.2 \mathrm{~m}$, general view under scanning electron microscope, sculpture in central portion and dorsal side; D - Letyatkin Cape, Yakutia, Russian Federation, general view; E-F - Tom Creek, Canada, sample AVR-17TC 9a, general view. Scale bars: $1 \mathrm{~mm}$ for D-F; $0.1 \mathrm{~mm}$ for A-B; $0.01 \mathrm{~mm}$ for $\mathrm{C}$.

Рис. 1. Ископаемые эфиппиумы, принадлежащие таксонам группы видов Daphnia (Daphnia) pulex. A-C - Мыс Саблера, Таймыр, Российская Федерация, образец 25,2 м, общий вид под сканирующим электронным микроскопом, скульптура в центральной части эфиппиума и спинной край; D - Мыс Летяткина, Якутия, Российская Федерация, общий вид; E-F - Том Крик, Канада, образец AVR-17TC 9а, общий вид. Масштабные линейки: 1 мм для D-F; 0,1 мм для A-B; 0,01 мм для C. 
et al., 2005; Popova et al., 2016). Recently we demonstrated that representatives of this subgenus were common in the Beringian region in the Pleistocene, although they are absent there now (Kirillova et al., 2016; Kotov et al., 2018b). It is even possible, at least in some cases, to identify the exact species, e.g. Kotov et al. (2018) revealed ephippia of $D$. (Ctenodaphnia) magna in the fur of the mammoth found in MIS3 deposits in the Allaikha River basin (Sakha Republic, Russian Federation). Ephippium of this taxon could be identified based on well-developed scales on its surface (see Fig. 3). But still we do not have a key for determination of species based on ephippia, even for the Northern Palaearctic.

Orlova-Bienkowskaja (2001) concluded that ephippia of Simocephalus do not carry specific diagnostic characters, but our studies of Pleistocene fossils have revealed discrete types of ephippia, even in the same locality (Fig. 3). Few cases of successful discrimination of Ceriodaphnia species using ephippia were made previously (Bottrell, Newsome, 1976; Berner, 1985), but our recent investigation confirmed that at least main species groups of Ceriodaphnia could be identified based on ephippial morphology under both optical and scanning electron microscope (Kotov et al., 2018).

To date, only some recent daphniids like Daphnia (Ctenodaphnia) or Ceriodaphnia could be identified adequately up to species level using ephippium morphology, but studies of recent ephippia need to be continued, so that some differences between the ephippia of other daphniid species could be found in the future. At the same time, there is no existing evidence that Pleistocene ephippia belong to some extinct species. In contrast, they are apparently closest relatives, or exactly conspecific, to recently existing species. This conclusion agrees with aforementioned molecular-clock calculations (Colbourne, Hebert, 1996; Taylor et al., 1996): even "the youngest" species groups of the genus Daphnia, such as D. cucullata/ hyalina/ galeata/ rosea/ thorata-clade, exist at least 4-6 Mya, and significantly more ancient lineages also are found (Colbourne, Hebert, 1996; Smirnov, Kotov, 2018).

\section{Quantitative methods for analysis of the ephippia}

We are sure that in reality ephippia were (and are) seen by different palaeoinvestigators often in the Pleistocene or even in older sites, but the authors were (and are) not able to identify such remains. For example, Daphnia remains from Alaska, Yukon and Northwest Territories mentioned by Mattews \& Telka (1997) apparently belonged to ephippia. Daphniid ephippia were found in many recently studied Pleistocene cores and outcrops of different age (Kienest et al., 2011, Kuzmina et al., 2014; Kuzmina, 2015). They are very common component of these deposits and usually absence of their records in Pleistocene-Pliocene localities means that the authors did not look for them. In addition, ephippia are reported from the feces (Kirillova et al., 2012a), gut contents (Kosintsev et al., 2012a, b) and fur (Kirillova et al., 2015, 2016b) of large Pleistocene mammals.

Cladocerans are a powerful tool for paleolimnological interpretations and hence for detection of changes in past environmental conditions (Korhola, Rautio, 2001, Rautio, 2007). Many previous articles describe quantitative methods in the studies of chydorid cladoceran remains (Sarmaja-Korjonen, 2003; Bennike et al., 2004; Smirnov, 2010; Frolova et al., 2013). In the future, if Pleistocene ephippia are collected properly from lake sediment cores or natural outcrops and then properly identified, they can be a promising material that can be used for attempts to find correlations between the number of animal remains and the changes of environmental parameters such as temperature, $\mathrm{pH}$, nutrients (Rautio, 2007). Recently a similar technique has been developed for chydorid ephippia (Sarmaja-Korjonen, 2003; Bennike et al., 2004).

It is important to take into consideration the attempts to interpret cladoceran response to a single environmental variable and the possibility of misinterpretation of such a relationship (Jeppesen et al., 2001; Rautio, 2007). Of course, a maximum effect has palaeoreconstructions that use several independent palae- 

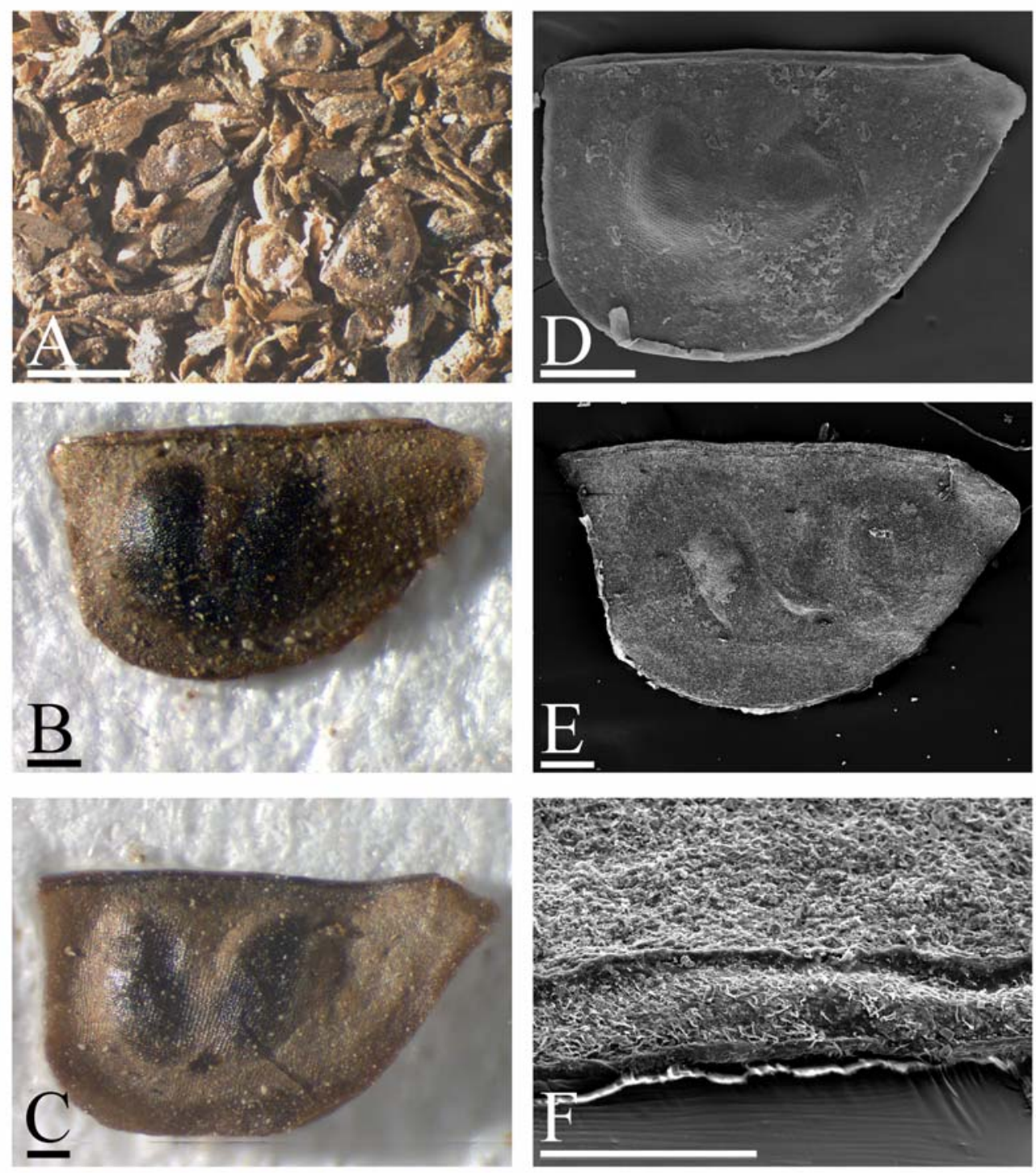

Fig. 2. Fossil ephippia of Daphnia (Daphnia) longispina group.

A-D - Old Crow, Yukon, Canada, sample OC-B45, deposit filled by ephippia and general view of different ephippia; E-F - Section Palisades, Alaska, USA, sample AL-4-05 B15, general view of ephippium and its dorsal side. Scale bars: $1 \mathrm{~mm}$ for A-C; $0.1 \mathrm{~mm}$ for D-F.

Рис. 2. Ископаемые эфиппиумы, принадлежащие видам группы Daphnia (Daphnia) longispina.

A-D - Олд Кроу, Юкон, Канада, образец ОС-B45, порода с многочисленными эфиппиумами и общий вид нескольких эфиппиумов; E-F - Разрез Палисайдс, Аляска, CША, образец AL-4-05 B15, общий вид эфиппиума и его спинной край. Масштабные линейки: 1 мм для $\mathrm{A}-\mathrm{C} ; 0,1$ мм для $\mathrm{D}-\mathrm{F}$.

Рис. 3. Ископаемые эфиппиумы Daphniidae.

A-D - Daphnia (Ctenodaphnia) magna, карьер 48, Альберта, Канада, общий вид эфиппиума, скульптура в его центральной части при двух разных увеличениях, задняя часть эфиппиума с включенной в его состав хвостовой иглой; E-F - Олд Кроу, Юкон, Канада, образец ОC-B45, Simocephalus sp., эфиппиум морфотипа 1, общий вид и скульптура в центральной части; G-H - Олд Кроу, образец OC-B45, Simocephalus sp., эфиппиум морфотипа 2, общий вид и скульптура в его центральной части. Масштабные линейки: 1 мм для А; 0,1 мм для В-Н. 

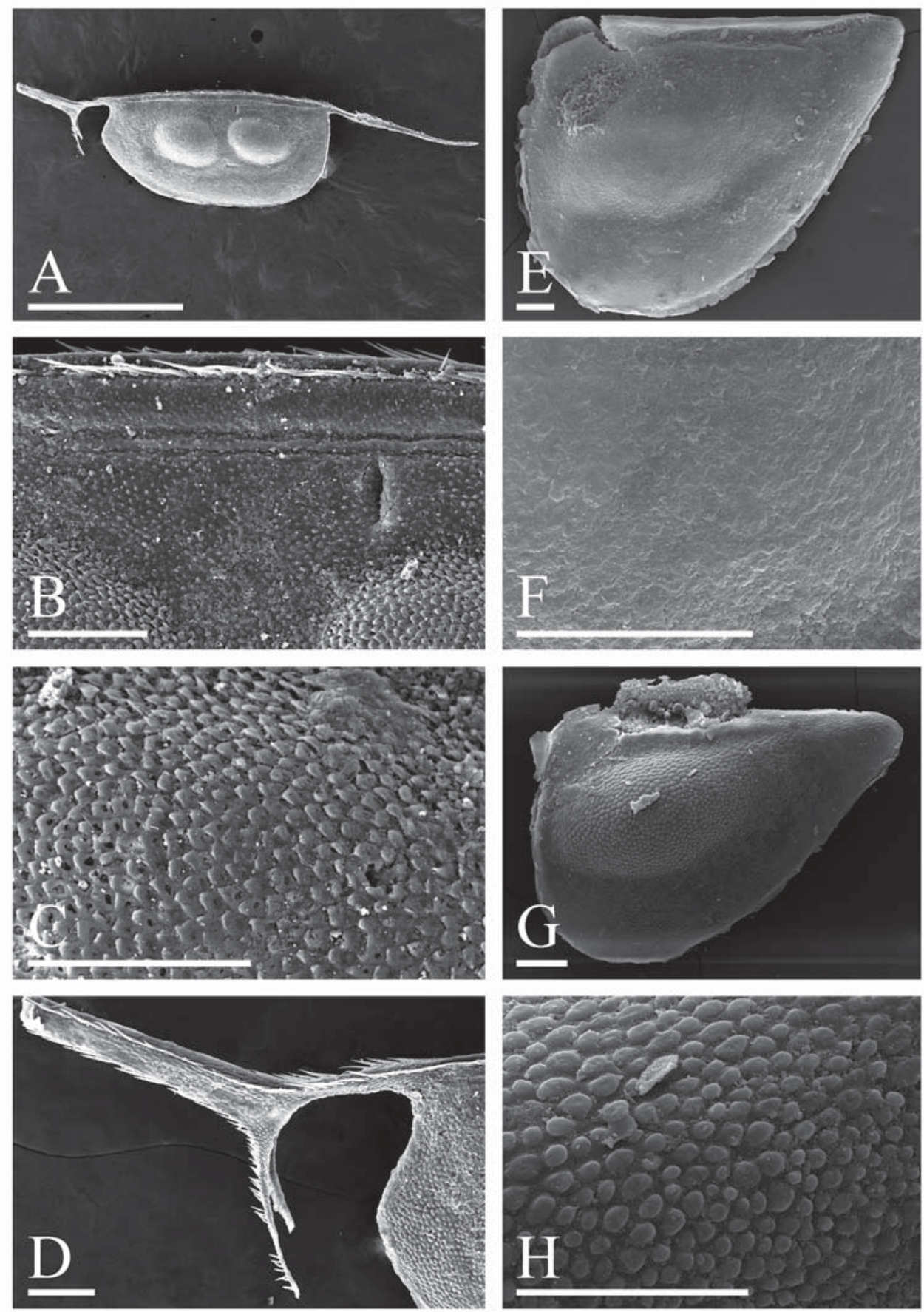

Fig. 3. Fossil ephippia of Daphniidae.

A-D - Daphnia (Ctenodaphnia) magna, pit No 48, Alberta, Canada, general view of ephhippium, sculpture in its central portion in two different magnifications, posterior projection of ephippium with caudal needle incorporated; EF - Old Crow, Yukon, Canada, sample OC-B45, Simocephalus sp., ephippium of morphotype 1, general view and sculpture in central portion; G-H - Old Crow, sample OC-B45, Simocephalus sp., ephippium of morphotype 2, general view and sculpture in central portion. Scale bars: $1 \mathrm{~mm}$ for A; $0.1 \mathrm{~mm}$ for B-H. 
oproxies (Subetto et al., 2017; Wetterich et al., 2018), and the cladoceran data can be a very important proxy for using such an approach (Kienast et al., 2011). Moreover, just the ephippia, being properly identified, could be a basis for zonation of the cores, similarly to pollen analysis. In an article by Frolova et al. (2017) such zonation of a sediment core from Central Yakutia and palaeoecological reconstruction was successfully conducted using ephippium analysis. Sarmaja-Korjonen (2003) concluded that presence of numerous chydorid ephippia in some layers of a core is correlated with the periods of environmental stresses, i.e. changes of climate and changes of the predation regime (when the periods of gamogenetic reproduction are started earlier and occupy large portion of the life cycle). Analogous conclusions could be proposed for the Pleistocene sections, although some other factors could affect the size of ephippia. For example, the size of ephippia could reflect a press of planktivorous fish in the past, as the juveniles of different fish species prefer large specimens (Jeppesen et al., 2002; Rautio, 2007; Smirnov, 2010). But for such works we need to be sure that the method does not have any artefacts of disproportional size selection of the fossil material.

Special attention could be paid to appearance and disappearance of some species, including indicators of some particular environmental conditions. Such approach could be helpful also for tracing the appearance-disappearance of some species due to well-known strong climatic changes during the Pleistocene. It must be taken into consideration that appearance of remains of some species at some sections is well-known in case of detection of biological invasions of some Daphnia species (Kerfoot et al., 2004; Mergeay et al., 2006b).

Afore mentioned disproportion of the cladoceran studies (more in late Holocene, and sparse in early Holocene and Pleistocene) could be caused by human factor or differences in the methods and equipment used by different investigators. Several reviews and monographs have been completed on lake sediment coring and the reader is referred to these compilations for more details (e.g., Cushing, Wright, 1965, Wright et al., 1965; Acker, 1974; Murdoch, Azcue, 1995; Glew et al., 2001). But generally, short-term history of a certain lake is usually studied by a simple tube corer or gravity corer (Glew et al., 2001; Brendonck, De Meester, 2003). Such sediments are not so thick, and a core representing all the water body history is easily extracted. Deeper sediments have to be excavated by a heavy drilling with gravity corer or piston corer (Cushing, Wright, 1965; Brendonck, De Meester, 2003), often from special rafts, or from ice; this is complicated and expensive work. But the deep lake long cores are widely used for pollen (Anderson, Lozhkin, 2015), chironomid (Porinchu, Cwynar, 2002; Nazarova et al., 2017), diatom (Laing et al., 1999; Palagushkina et al., 2017), and other types of analysis (Smirnov, 2018). For example the core from El'gygytgyn Lake provides a continuous record of pollen and diatom data since at least the Middle Pleistocene (Nowaczyk et al., 2002; Cherepanova et al., 2007; Lozhkin et al., 2007). Such unique core samples were treated for traditional microfossil analysis, but large- or middle-sized remains (such as insects or cladocerans) were overlooked during such studies.

\section{Use in palaeoreconstructions and sed- imentation studies}

In some cases (e.g., Old Crow or Titaluk see Kuzmina et al., 2019) presence of ephippia in deposits in a significant number apparently is correlated with their lake-bog origin. Therefore, data on cladoceran analysis agree well with data from other types of the analysis. But cases of a contradiction between cladoceran analysis and other palaeoproxies can be even more interesting. For example, an analysis of plant macro-fossils in a SAO-1 section (Late Pleistocene of Taimyr) by Kienast et al. (2001: 237) revealed "lack of hydropytes and marsh plants and the predominance of xerophytes", reflecting cryoarid climatic conditions. At the same time, numerous ephippia were found in such palaeolocalities. These remains of freshwater animals unambiguously established the presence of some water bodies (most probably, temporary ponds) during that time. 
One of the most important and still unsolved questions of Quaternary Geology in the NorthEast Eurasia is the origin of the ice rich silty sediment - so-called "Yedoma" (Sher, 1997). There are two main hypotheses on the Yedoma origin: eolian and polygenetic (Strauss et al., 2017). Eolian theory suggests that the loess-like sediment is true loess - wind transported dust (Tomirdiaro, 1996; Beget, 2001). Poligenetic theory proposes that tiny loess-like silt is product of a frost weathering of the different types of sediments (Konishchev, 1987). While a wind input could take part in the sediment accumulation, the Yedoma is composed of cryo-transformed fluvial or slope sediments. Both theories have advantages and disadvantages, and additional evidence is necessary. Obviously, deposit of the eolian origin should contain mostly terrestrial species of plant and arthropods, but fluvial sediments should be full of aquatic and riparian species. Numerous insect samples from north-western North America (Matthews, Telka, 1997; Matthews et al., 2019) and northeastern Siberia (Kiselev, 1981; Kiselev, Nazarov, 2009) show that aquatic and riparian species are quite rare or absent in the loess-like sediment. That confirms the eolian theory. But there are obvious exceptions to this rule. For example, our samples from Old Crow sections (Kuzmina et al., 2014) usually yield little or no aquatic-riparian invertebrates except the sample OC-B-45 which is poor of insects but is overfilled by daphniid ephippia. This layer (at first glance indistinguishable from surround deposits) evidently has been formed due to a water body existence, probably small temporary pool. This example suggested that predominantly eolian accumulation could be complicated by other factors. Ephippia can play an important role as a special marker of lacustrine deposits and can help to discover hidden gaps in sediment accumulation. Such "geological" benefit of ephippia is not yet appreciated.

\section{Using of ephippia for particular types of analyses}

Certain types of analyses of qualitative subsamples containing ephippia from particular layers of a core could be interesting for tracing environmental changes. For example, a concentration of melanin and spectral absorbance of carapace remains are variables related to past UV radiation exposure (Rautio, Korhola, 2002; Nevalainen, Rautio, 2014). A very important direction of ephippium palaeo-analysis is a study of stable isotopes, demonstrating past dietary patterns and some palaeoclimatic conditions (Schilder et al., 2015a, b). Finally, permafrost or non-permafrost ephippia can be used for AMS ${ }^{14} \mathrm{C}$ dating (Child, Werner, 1999). It is known that the radiocarbon dating of late-Quaternary sediments from high-latitude lakes is often complicated by the influx of old carbon, reservoir effects, or both. But situations when fragments of terrestrial origin are absent in some layers are usual, and in such cases remains of water arthropods like chironomids (Fallu et al., 2004) could be used keeping in mind aforementioned effects making the ages younger. Sometimes cladoceran ephippia are even more numerous than chironomid head capsules, and can be tested as a source of the carbon for AMS dating.

Chance to extract DNA from the permafrost samples and to hatch the specimens

Even in non-permafrost samples, like lake sediments, DNA is stored in daphniid ephippia over centuries and sometimes even over millennia (Mergeay et al., 2004). DNA was successfully extracted from Late Holocene ephippia (Limburg, Weider, 2002; Marková et al., 2006; Mergeay et al., 2004, 2006a; Fritsch, 2014). Permafrost ephippia also can be used for DNA extractions, as for other subfossil animals (Willersley et al., 2003; Rautio, 2007). Unfortunately, our attempts to extract DNA from ephippia described above were not successful (due to improper techniques of sampling, with intensive rinsing with water in the field). For DNA study it is necessary to extract ephippia from permafrost cores or outcrops in a more accurate way. It will give us a chance to identify species of Daphnia, and accurately estimate differences 
of a pre-glaciation fauna from recent. Genetics of the microparasites could also be studied for permafrost ephippia, similarly with analogous studies for the Upper Holocene (Decaestecker et al., 2004).

It is known that at least some ephippia are vital in lake sediments during hundreds of years (Cäceres, 1998). Successful hatching of most Daphnia resting eggs has been restricted to ca. 60-70 years, or less (Marková et al., 2006), but recently hatchlings were obtained from about 600 year-old ephippia excavated from lake sediments (Frisch et al., 2014). We believe that the resting eggs in daphniid ephippia in permafrost, being better protected as compared with lake sediments, probably can be artificially hatched. If yes, we will have a unique source of information on the genetics, physiology etc. of the animals from past epochs.

Few successful attempts to grow Pleistocene plants from seeds excavated from the permafrost have been made (Yashina et al., 2012). Several authors pointed out that ephippia are analogues of plant seeds (Figuerola, Green, 2002; Van Damme, Sinev, 2013; Kotov, 2013). We believe that some ephippia could be hatched from permafrost, comparable to plant seeds.

Important notes on sampling in the field and lab treatment

Quaternary cladocerans lie between macroand micro-fossils in size. They could be excavated from both borehole cores and from natural outcrops. Such cores usually have a restricted volume. Natural outcrops permit samples of a large volume. In this case we recommend wet screening of sediments through screening boxes. The size of the mesh must be near $0.1 \mathrm{~mm}$. The net is fixed on the bottom of the screening box, water comes from the bottom to prevent the sample from modern contamination (as modern microscopic animals are filtered out). The best sediment for such examination is silt with tiny plant debris.

The best samples for DNA study come from frozen sediments, and the samples must be kept frozen until lab examination. The task to keep samples frozen makes field work much more complicated; an easier method is to pick up the ephippia in the field and to put them in alcohol or RNA buffer (in the latter case they need to be partly crashed as the ephippium shell and egg membrane could prevent a successive fixation of embryo).

Note that Pleistocene sediments contain remains of other cladocerans, especially from the families Chydoridae and Bosminidae, which form the bulk of Late Holocene cladoceran remains and are a main material for cladoceran analysis from sub-fossil tanatocenoses (Frey, 1964, 1986; Smirnov, 1984, 2010). But such remains are missed in sampling by palaeobotanist and palaeoentomologists, so we need to use a special method (see above).

\section{Conclusions}

1. Cladoceran remains, mostly Daphnia ephippia, are widespread in the permafrost deposits of Northern Eurasia and North America. We can expect their presence in all types of terrestrial deposit from all regions of the permafrost zone.

2. Ephippia of cladocerans and Daphniidae (Branchiopoda: Cladocera) in particular could be used for reconstruction of the past environment, palaeoclimate, condition of sediment accumulation, and the ephippium analysis could potentially be widely applied in Quaternary ecology.

3. For reinforcing of the ephippium analysis new knowledge on resting eggs and ephippium morphology, and further development of comprehensive identification keys of cladoceran ephippia, are strongly required.

4. Resting eggs of Daphnia and other cladocerans could be a good material for DNA studies and even hatching of specimens, not widely used at the moment. Therefore, the ephippia could be potentially an important source for quantitative information for palaeoecological reconstructions. But such studies need to be discrete rather than a byproduct of paleo-entomological or paleo-botanical studies. The ephippia need to be collected using adequate methods, 
i.e. sieves with a small mesh size (not more that $0.1 \mathrm{~mm}$ ). Moreover, special studies of recent taxa with the aim of elucidating their identification based on ephippia are needed urgently.

\section{Acknowledgements}

Many thanks to F. Kienast (Senckenberg Research Institute, Weimar, Germany), A. Reyes, B. Jensen (University of Alberta, Edmonton, Canada) and G. Seal (Palaeontology lover, Edmonton, Canada) for samples containing fossil ephippia. A. Sher, P. Matheus (U of Alaska, Faibanks, USA, now a farmer in Yukon), D. Froese (U of Alberta), G. Zazula (Yukon Government, Whitehorse), A. Reyes and B. Jensen helped S.K. in the field. We are very grateful to L.B. Nazarova for critical comments on earlier draft and for R.J. Shiel for linguistic corrections. SEM works were carried out at the Joint Usage Center "Instrumental methods in ecology" at A.N. Severtsov Institute of Ecology and Evolution. Study of Taimyr ephippia is performed according to the Russian Government Program of Competitive Growth of Kazan Federal University. Study of Beringian cladocerans is supported by the Russian Foundation for Basic Research (grant 18-04-00398). LF was supported by Russian Scientific Foundation (grant 16-17-10118).

This paper is dedicated to the 80th anniversary of A.V. Sher (1939-2008), renown Russian Quaternary ecologist.

\section{References}

Alhonen P. 1970. On the significance of the planctonic/ littoral ratio in the cladoceran stratigraphy of lake sediments // Comment. Biol. Vol.35. P.1-9.

Amsinck S.L., Jeppesen, E., Verschuren D. 2007. Use of cladoceran resting eggs to trace climate driven and anthropogenic changes in aquatic ecosystems // V.R. Alekseev, B. De Stasio, J.J. Gilbert (eds.). Aquatic Invertebrates. Diapause in Aquatic Invertebrates. Theory and Human Use. Dordrecht: Springer. P.135-157.

Anderson P.M., Lozhkin A.V. 2015. Late Quaternary vegetation of Chukotka (Northeast Russia), implications for Glacial and Holocene environments of Beringia // Quaternary Sci. Rev. Vol.107. P.112-128.

Acker W.L. 1974. Basic procedures for soil sampling and core drilling. Scranton, Pennsylvania: Acker Drill Co. Inc. $246 \mathrm{p}$.

Beget J.E. 2001. Continuous late Quaternary proxy climate records from loess in Beringia // Quaternary Sci. Rev. Vol.20. No.1-3. P.499-507.
Bennike O., Böcher J. 1990. Forest-tundra neighbouring the North Pole: Plant and insect remains from the PlioPleistocene Kap København Formation, North Greenland // Arctic. Vol.43. P.331-338.

Bennike O., Böcher J. 1992. Early Weichselian interstadial land biotas at Thule, Northwest Greenland // Boreas. Vol.21. P.111-117.

Bennike O., Sarmaja-Korjonen K., Seppanen A. 2004. Reinvestigation of the classic late-glacial Bølling Sø sequence, Denmark: chronology, macrofossils, Cladocera and chydorid ephippia // J. Quaternary Sci. Vol.19. P.465-478.

Benzie J.A.H. 2005. The genus Daphnia (including Daphniopsis) (Anomopoda: Daphniidae) // H. J. Dumont (ed.). Guides to the identification of the microinvertebrates of the continental waters of the world. Vol.21. Ghent: Kenobi Productions \& Leiden: Backhuys Publishers. 376 p.

Berner D.B. 1985. Morphological differentiation among species in the Ceriodaphnia cornuta complex (Crustacea, Cladocera)// Verh. Int. Verein. Limnol. Vol.22. P.3099-3103.

Bottrell H.H., Newsome T. 1976. Body length, size and identification of the ephippia of Ceriodaphnia megalops and Ceriodaphnia pulchella // Freshwat. Biol. Vol.6. P.405-408.

Brendonck L., De Meester L. 2003. Egg banks in freshwater zooplankton: evolutionary and ecological archives in the sediment // Hydrobiologia. Vol.491. P.65-84.

Burns J.A. 2004. Late Pleistocene Lemmings (Lemmus trimucronatus and Dicrostonyx groenlandicus; $\mathrm{Mu}-$ ridae: Rodentia) from Alberta, Canada // J. Mammal. Vol.85. P.379-383.

Cañellas-Boltà N., Rull V., Sáez A., MargalefO., Giralt S., Pueyo J.J., Birks H.H., Birks H.J.B., Pla-Rabes S. 2012. Macrofossils in Raraku Lake (Easter Island) integrated with sedimentary and geochemical records: towards a palaeoecological synthesis for the last 34,000 years // Quaternary Sci. Rev. Vol.34. P.113-126.

Cäceres C.E. 1998. Interspecific variation in the abundance, production and emergence of Daphnia diapausing eggs // Ecology. Vol.79. P.1699-1710.

Cherepanova M.V., Snyder J.A., Brigham-Grette J. 2007. Diatom stratigraphy of the last $250 \mathrm{ka}$ at Lake El 'gygytgyn, northeast Siberia // J. Paleolimnol. Vol.37. P.155-162.

Child J.K., Werner A., 1999. Evidence for a hardwater radiocarbon dating effect, Wonder Lake, Denali National Park and Preserve, Alaska, USA // Geogr. Phys. Quat. Vol.53. P.407-412.

Colbourne J.K., Hebert P.D.N. 1996. The systematics of North American Daphnia (Crustacea: Anomopoda): a molecular phylogenetic approach // Phil. Trans. Roy. Soc. London. B. Vol.351. P.349-360.

Colman S.M. 1996. Continental drilling for paleoclimatic records: recommendations from an International Workshop // S.M. Colman (ed.). Pages Workshop Report. Series 96-4. 104 p.

Crease T.J., Omilian A.R., Costanzo K.S., Taylor D.J. 2012. Transcontinental phylogeography of the Daphnia pulex species complex. PLoS ONE. Vol.7. No.10. e46620.

Cromer L., Gibson J.A.E., Swadling K.M., Hodgson D.A. 2006. Evidence for a lacustrine faunal refuge in the 
Larsemann Hills, East Antarctica, during the Last Glacial Maximum // J. Biogeogr. Vol.33. P.1314-1323.

Cushing E.T., Wright H.E. 1965. Hand operated piston corers for lake sediments // Ecology. No. 46. P.380384 .

Decaestecker E., Lefever C., De Meester L. 2004. Haunted by the past: evidence for dormant stage banks of microparasites and epibionts of Daphnia // Limnol. Ocean. Vol.49. P.1355-1364.

Deevey E.S. 1942. Studies on Connecticut lake sediments. III. The biostratonomy of Lindsey Pond // Amer. J. Sci. Vol.240. P.233-264.

Dereviagin A., Siegert C., Troshin E., Simonov E. 1997. Permafrost landscapes and geocryology of Cape Sabler // Repts Polar Res. Vol. 237. P.89-97.

Dickinson K.A., Swain F.M. 1967. Late Cenozoic freshwater Ostracoda and Cladocera from northeastern Nevada // J. Paleontol. Vol.41. P.335-350.

Duigan C.A., Birks H.H. 2000. The late-glacial and earlyHolocene palaeoecology of cladoceran microfossil assemblages at Krakenes, western Norway, with a quantitative reconstruction of temperature changes // J. Paleolimnol. Vol.23. P.67-76.

Fallu M.-A., Pienitz R., Walker I.R., Overpeck J. 2004. AMS ${ }^{14} \mathrm{C}$ dating of tundra lake sediments using chironomid head capsules // J. Paleolimnol. Vol.31. P.1122.

Figuerola J., Green A.J. 2002. How frequent is external transport of seeds and invertebrate eggs by waterbirds? A study in Doñana, SW Spain // Arch. Hydrobiol. Vol.155. P.557-565.

Froese D., Smith D.G., Westgate J.A. Ager T.A., Preece S.J., Sandhu A., Enkin R.J., Weber F. 2003. Recurring middle Pleistocene outburst floods in east-central Alaska // Quaternary Res. Vol.60. P.50-62.

Frey D.G. 1958. The late-glacial Cladoceran fauna of a small lake // Arch. Hydrobiol. Vol.54. P.209-275.

Frey D.G. 1964. Remains of animals in Quaternary lake and bog sediments and their interpretation // Ergebn. Limnol. Vol.2. No.1. P.1-114.

Frey D.G. 1986. Cladocera analysis // Berglund B.E. (ed.). Handbook of Holocene paleoecology and paleohydrology. J. Wiley \& Sons Ltd. Vol.32. P.667-692.

Frey D.G. 1991. First subfossil records of Daphnia headshield and shells (Anomopoda, Daphniidae) about 10000 years old from nothernmost Greenland, plus Alona guttata (Chydoridae) // J. Paleolimnol. Vol.6. P.192-197.

Frisch D., Morton P.K., Chowdhury P.R., Culver B.W., Colbourne J.K., Weider L.J., Jeyasingh P.D. 2014. A millennial-scale chronicle of evolutionary responses to cultural eutrophication in Daphnia // Ecol. Lett. Vol.17. P.360-368.

Frolova L., Frolova A. 2017. Implification of ephippium analysis (Cladocera, Branchiopoda, Crustacea) for reconstruction of past environmental changes in Central Yakutia, Russia // 17th Int. Multidiscip. Sci. GeoConf. SGEM 2017. Conf. Proc. Vol.17. No.41. P.481-486.

Frolova L.A., Ibragimova A.G., Ulrich M., Wetterich S. 2017. Reconstruction of the history of a thermokarst lake in the Mid-Holocene based on an analysis of subfossil Cladocera (Siberia, Central Yakutia) // Cont. Problems Ecol. Vol.10. No.4. P.423-430.

Frolova L.A., Nazarova L., Pestryakova L., Herzschuh U. 2013. Analysis of the effects of climate-dependent factors on the formation of zooplankton communities that inhabit Arctic lakes in the Anabar River basin // Contemp. Probl. Ecol. Vol.6. No.1. P.1-11.

Frolova L., Nazarova L., Pestryakova L., Herzschuh U. 2014. Subfossil Cladocera from surface sediment in thermokarst lakes in northeastern Siberia, Russia, in relation to limnological and climatic variables // J. Paleolimnol. Vol.22. P.107-119.

Fryer G. 1991. A daphnid ephippium (Branchiopoda: Anomopoda) of Cretaceous age // Zool. J. Linn. Soc. Vol.102. P.163-167.

Fryer G. 1995. Phylogeny and adaptive radiation within the Anomopoda: a preliminary exploration // Hydrobiologia. Vol.307. P.57-68.

Glagolev S.M. 1983. [A structure of ephippium surface in Daphniidae (Crustacea, Cladocera) by the data of scanning electron microscopy] // Zool. Zhurn. Vol.62. No.9. P.1422-1424 [in Russian].

Glew J.R., Smol J.P., Last W.M. 2001. Sediment core collection and extrusion // W.M. Last, J.P. Smol (eds.). Tracking Environmental Change Using Lake Sediments. Vol.1.: Basin analysis, coring, and chronological techniques. Dordrecht, Boston, London: Kluwer Acad. Publ. P.73-105.

Goulden C.E. 1968. The systematics and evolution of the Moinidae // Trans. Amer. Phil. Soc. Philad. N. Ser. Vol.58. P.1-101.

Gracheva R., Vandenberghe J., Sorokin A., Malyasova E., Uspenskaya O. 2015. Mesolithic-Neolithic settlements Minino 2 and Zamostye 5 in their geo-environmental setting (Upper Volga Lowland, Central Russia) // Quaternary Intern. Vol.370. P.29-39.

Hann B.J., Karrow P.F. 1984. Pleistocene paleoecology of the Don and Scarborough Formations, Toronto, Canada, based on cladoceran microfossils at the Don Valley Brickqard // Boreas. Vol.13. P.377-391.

Hann B.J., Karrow P.F. 1993. Comparative analysis of cladoceran microfossils in the Don and Scarborough Formations, Toronto, Canada // J. Paleolimnol. Vol.9. P.223-241.

Hegna T.A., Kotov A.A. 2016. Ephippia belonging to Ceriodaphnia Dana, 1853 (Cladocera: Anomopoda: Daphniidae) from the Lower Cretaceous of Australia // Palaeontol. Electron. Vol.19.3.40A. P.1-9.

Jeppesen E., Leavitt P., De Meester L., Jensen J.P. 2001. Functional ecology and palaeolimnology: using cladoceran remains to reconstruct anthropogenic impact // TREES. Vol.16. P.191-198.

Kadota S. 1973. A quantitative study of microfossils in the core sample from Lake Biwa-ko // Jap. J. Limnol. Vol.34. P.103-110.

Kerfoot W.C., Ma X., Lorence C.S., Weider L.J. 2004. Toward resurrection ecology: Daphnia mendotae and D. retrocurva in the coastal region of Lake Superior, among the first successful outside invaders? // J. Great Lakes Res. Vol.30. Suppl.1. P.285-299. 
Kienast F., Siegert C., Dereviagin A., Mai D.H. 2001. Climatic implications of Late Quaternary plant macrofossil assemblages from the Taymyr Peninsula, Siberia // Global Planet. Change. Vol.31. P.265-281.

Kienast F., Wetterich S., Kuzmina S., Schirrmeister L., Andreev A.A., Tarasov P., Nazarova L., Kossler A., Frolova L., Kunitsky V.V. 2011 Paleontological records prove boreal woodland under dry inland climate at today's Arctic coast in Beringia during the last interglacial // Quaternary Sci. Rev. Vol.30. P.2134-2159.

Kirillova I.V., Argant J., Lapteva E.G., Korona O.M., Van der Plicht J., Zinoviev E.V., Kotov A.A., Chernova O.F., Fadeeva E.O., Baturina O.A., Kabilov M.R., Shidlovskiy F.K., Zanina O.G., 2016a. The diet and environment of mammoths in North-East Russia reconstructed from the contents of their feces // Quaternary Intern. Vol.406. P.147-161.

Kirillova I.V., Kotov A.A., Trofimova S.S., Zanina O.G., Lapteva E.G., Zinoviev E.V., Chernova O.F., Fadeeva E.O., Zharov A.A., Shidlovskiy F.K. 2015. Fossil fur as a new source of information on the Ice Age Biota // Dokl. Biol. Sci. Vol.460. P.48-51.

Kirillova I.V., Van der Plicht J., Gubin S.V., Zanina O.G., Chernova O.F., Lapteva E.G., Trofimova S.S., Zinoviev E.V., Zharov A.A., Fadeeva E.O., Van Kolfschoten T., Shidlovskiy F.K., Kotov A.A. 2016 b. Taphonomic phenomen of ancient mammal fur from Glacial Beringia // Boreas. Vol.45. P.455-469.

Kiselev S.V., Nazarov V.I. 2009. Late Cenozoic Insects of Northern Eurasia // Paleontol. J. Suppl. Vol.43. No.7. P.1-128.

Kiselev S.V. 1981. [Late Cenozoic Coleoptera of NorthEast Siberia]. Moscow: Nauka. 116 p. [In Russian]

Konishchev V.N. 1987. Origin of loess-like silt in Northern Yakutia, USSR // GeoJournal. Vol.15. P.135-139.

Korhola A. , Rautio M. 2001. Cladocera and other branchiopod crustaceans // J.P. Smol, J.B. Birks, W.M. Last (eds). Tracking Environmental Change Using Lake Sediments. Vol.1. Zoological Indicators. Dordrecht: Kluwer Acad. Publ. P. 5-41.

Kosintsev P.A., Lapteva E.G., Korona O.M., Zanina O.G. 2012 a. Living environments and diet of the Mongochen mammoth, Gydan Peninsula, Russia // Quaternary Intern. Vol.276-277. P.253-268.

Kosintsev P.A., Lapteva E.G., Trofimova S.S., Zanina O.G., Tikhonov A.N., van der Plicht J. 2012b. Environmental reconstruction inferred from the intestinal contents of the Yamal baby mammoth Lyuba (Mammuthus primigenius Blumenbach, 1799) // Quaternary Intern. Vol.255. P.231-238.

Kotov A.A. 2009. New finding of Mesozoic ephippia of the Anomopoda (Crustacea: Cladocera) // J. Nat. Hist. Vol.43. P.523-528.

Kotov A.A. 2013. [Morphology and phylogeny of the Anomopoda (Crustacea: Cladocera)]. Moscow: KMK Sci. Press. 638 pp. [In Russian]

Kotov A.A. 2015. A critical review of the current taxonomy of the genus Daphnia O. F. Müller, 1785 // Zootaxa. Vol.3911. P.184-200.

Kotov AA., Ibragimova A.G., Neretina A.N. 2018. Species identification in Ceriodaphnia Dana (Crustacea: Cla- docera) from European Russia based on the ephippium morphology // Zootaxa. Vol.4527. P. 105-123.

Kotov A.A., Taylor D.J. 2011. Mesozoic fossils (>145 Mya) suggest the antiquity of the subgenera of Daphnia and their coevolution with chaoborid predators // BMC Evol. Biol. Vol.11. No.129. doi:10.1186/14712148-11-129

Kotov A.A., Wappler T. 2015. Findings of Daphnia (Ctenodaphnia) Dybowski et Grochowski (Branchiopoda: Cladocera) in Cenozoic volcanogenic lakes in Germany, with discussion of their indicator value // Palaeontol. Electron. Vol.18.2.40A. P.1-9.

Kotov A.A., Zharov A.A., Chernova O.F., Neretina A.N., Gololobova M.A., Trofimova S.S., Zinovyev E.V., Izymova E.I., Zanina O.G., Kirillova I.V., Shidlovskiy F.K. 2018. [Crustacea (Branchiopoda) in the complex of organic remains from mammoth hair] // Zool. Zhurn. Vol.97. No.10. P.1300-1314 [in Russian].

Kuzmina S.A. 2015. Quaternary Insects and Environment of the Northeastern Asia // Paleontol. J. Suppl. Vol.49. No.7. P.1-189.

Kuzmina S.A., Elias S.A., Kotov A.A. 2019. Late Quaternary insects and freshwater invertebrates of the Alaskan North Slope and paleoenvironmental reconstructions in Arctic Alaska // Invertebrate Zool. Vol.16. No.2. P.89-125.

Kuzmina S., Froese D.G., Jensen B.J.L., Hall E., Zazula G.D. 2014. Middle Pleistocene (MIS 7) to Holocene fossil insect assemblages from the Old Crow basin, northern Yukon, Canada // Quaternary Intern. Vol.341. P.216-242.

Lai Xing-rong \& Li Ying-pei 1987. Ephippia of Cladocera from Tertiary of China // Acta Palaeontol. Sin. Vol.26. P.171-180.

Laing T.E., Rühland K.M., Smol J.P. 1999. Past environmental and climatic changes related to tree-line shifts inferred from fossil diatoms from a lake near the Lena River Delta, Siberia // Holocene. Vol.9. P.547-557.

Lea P.D., Elias S.A., Short S.K. 1991. Stratigraphy and Paleoenvironments of Pleistocene Nonglacial Deposits in the Southern Nushagak Lowland, Southwestern Alaska, U.S.A. // Arct. Alpine Res. Vol.23. P.375391.

Lemdahl G. 2000. Late-glacial and early-Holocene Coleoptera assemblages as indicators of local environment and climate at Krakenes Lake, western Norway // J. Paleolimnol. Vol.23. P.57-66.

Limburg P.A., Weider L.J. 2002. 'Ancient' DNA in the resting egg bank of a microcrustacean can serve as a palaeolimnological database // Proc. Roy. Soc. London. B. Vol.269. P.281-287.

Lozhkin A.V., Anderson P.M., Matrosova T.V., Minyuk P.S., Brigham-Grette J., Melles, M. 2007. Continuous record of environmental changes in Chukotka during the last 350 thousand years // Russ. J. Pac. Geol. Vol.1. P.550-555.

Lutz H. 1991. Autochthone aquatische Arthropoda aus dem Mittel-Eozän der Fundstätte Messel (Insecta: Heteroptera; Coleoptera; cf. Diptera-Nematocera; Crustacea: Cladocera) // Cour. Forsch.-Inst. Senckenberg. Bd.139. S.119-125. 
Mann D.H., Peteet D.M., Reanier R.E., Kunz M.L. 2002. Responses of an arctic landscape to Lateglacial and early Holocene climatic changes: the importance of moisture // Quaternary Sci. Rev. Vol.21. P.997-1021.

Marková S., Černý M., Rees D.J., Stuchlík E. 2006. Are they still viable? Physical conditions and abundance of Daphnia pulicaria resting eggs in sediment cores from lakes in the Tatra Mountains // Biologia. Vol.61. Suppl. 18. P.S135-S146.

Matheus P., Beget J., Mason O., Gelvin-Reymiller C. 2003. Late Pliocene to late Pleistocene environments preserved at the Palisades Site, central Yukon River, Alaska // Quaternary Res. Vol.60. P.33-43.

Matthews J.V., Jr., Telka A., Kuzmina S.A., 2019. Late Neogene insect and other invertebrate fossils from Alaska and Arctic/Subarctic Canada // Invertebrate Zool. Vol.16. No.2. P.126-153.

Matthews J.V., Jr., Telka A. 1997. Insect Fossils from the Yukon // H.V. Danks, J.A. Downes (eds.). Insects of the Yukon (Terrestrial Arthropods). Ottawa: Biological Survey of Canada. P.911-962.

Mergeay J., Declerck S., Verschuren D., De Meester L. 2006a. Daphnia community analysis in shallow Kenyan lakes and ponds using dormant eggs in surface sediments // Freshwater Biol. Vol.51. P.399-411.

Mergeay J., Verschuren D., De Meester L. 2005. Daphnia species diversity in Kenya, and a key to the identification of their ephippia// Hydrobiologia. Vol.542. P.261274.

Mergeay J., Verschuren D., De Meester L. 2006b. Invasion of an asexual American water flea clone throughout Africa and rapid displacement of a native sibling species// Proc. Roy. Soc. London. B. Vol.273. P.28392844.

Mergeay J., Verschuren D., Van Kerckhoven L., De Meester L. 2004. Two hundred years of a diverse Daphnia community in Lake Naivasha (Kenya): effects of natural and human-induced environmental changes // Freshwater Biol. Vol.49. P.998-1013.

Murdoch A., Azcue J.M. 1995. Manual of Aquatic Sediment Sampling Boca Raton: Lewis Publishers. 219 p.

Moldovan O.T., Mihevc A., Miko L., Constantin S., Meleg I., Petculescu A., Bosak P. 2011. Invertebrate fossils from cave sediments: a new proxy for pre-Quaternary paleoenvironments // Biogeosci. Discuss. Vol.8. P.3403-3434.

Nazarova L., Grebennikova T.A., Razjigaeva N.G., Ganzey L.A., Belyanina N.I., Arslanov K.A., Kaistrenko V.M., Gorbunov A.O., Kharlamov A.A., Rudaya N., Palagushkina O., Biskaborn B.K., Diekmann B. 2017. Reconstruction of Holocene environmental changes in Southern Kurils (North-Western Pacific) based on palaeolake sediment proxies from Shikotan Island // Glob. Planet. Change. Vol.159. P. 25-36.

Nevalainen L., Rautio M. 2014. Spectral absorbance of benthic cladoceran carapaces as a new method for inferring past UV exposure of aquatic biota // Quaternary Sci. Rev. Vol.84. P.109-115.

Nowaczyk N.R., Minyuk P., Melles M., Brigham-Grette J., Glushkova O., Nolan M., Lozkhin A.V., Stetsenko T.V., Anderson P.M., Forman S.L. 2002. Magneto- stratigraphic results from impact crater El'gygytgyn Lake, northeastern Siberia: a 300 kyr long highresolution terrestrial paleoclimatic record from the Arctic // Geoph. J. Intern. Vol.150. P.109-126.

Oksanen P.O., Kuhry P., Alekseeva R.N. 2003. Holocene development and Permafrost history of the Usinsk Mire, northeast European Russia // Géograph. Phys. Quatern. Vol.57. P.169-187.

Orlova-Bienkowskaja M.Ya. 2001. Daphniidae: genus Simocephalus // H.J. Dumont (ed.). Guides to the identification of the microinvertebrates of the continental waters of the World. Vol.17. Leyden: Backhuys. $130 \mathrm{p}$.

Ohtsuki H., Awano T., Tsugeki N.K., Ishida S., Oda H., Makino W., et al. 2015. Historical changes in the ecosystem condition of a small mountain lake over the past 60 years as revealed by plankton remains and Daphnia ephippial carapaces stored in lake sediments // PLoS ONE. Vol.10. No.3. e0119767.

Palagushkina O., Wetterich S., Biskaborn B., Nazarova L., Lenz J., Schwamborn G., Schirrmeister L., Grosse G. 2017. Diatom records and tephra mineralogy in pingo deposits of Seward Peninsula, Alaska // Palaeogeogr. Palaeoclimatol. Palaeoecol. Vol.479. P. 1-15.

Petrusek A., Hob ¿k A., Nilssen J.P., Skage M., Ėerný M., Brede N., Schwenk K. 2008. A taxonomic reappraisal of the European Daphnia longispina complex (Crustacea, Cladocera, Anomopoda) // Zool. Scr. Vol.37. P.507-519.

Pietrzak B., Slusarczyk M. 2006. The fate of the ephippia - Daphnia dispersal in time and space // Pol. J. Ecol. Vol.54. P.709-714.

Porinchu D.F., Cwynar L.C. 2002. Late-Quaternary history of midge communities and climate from a tundra site near the lower Lena River, northeast Siberia // J. Paleolimnol. Vol.27. P.59-69.

Rautio M. 2007. The use of Cladocera in paleolimnology // S.A. Elias (ed.). Encyclopedia of Quaternary Sciences. Elsevier, B.V. P. 2031-2039.

Popova E.V., Petrusek A., Kořínek V., Mergeay J., Bekker E.I., Galimov Y.R., Neretina T.V., Taylor D.J., Kotov A.A. 2016. Revision of the Old World Daphnia (Ctenodaphnia) similis group (Cladocera: Daphniidae) // Zootaxa. Vol.4161. P.1-40.

Rautio M., Korhola A. 2002. UV-induced pigmentation in subarctic Daphnia // Limnol. Oceanogr. Vol.47. P.295-299.

Richter G., Wedmann S. 2005. Ecology of the Eocene Lake Messel revealed by analysis of small fish coprolites and sediments from a drilling core // Palaeogeogr. Palaeoclimatol. Palaeoecol. Vol.223. P.147-161.

Rossolimo L.L. 1927. [Atlas of animal remains in peat and sapropel]. Moscow: Zhizn' i Znanie. 48 p. [In Russian with German Abstract]

Sacherová V., Hebert P.D.N. 2003. The evolutionary history of the Chydoridae (Crustacea: Cladocera) // Biol. J. Linn. Soc. Vol.79. P.629-643.

Sarmaja-Korjonen K. 2001. Correlation of fluctuations in cladoceran planktonic: littoral ratio between three cores from a small lake in southern Finland: Holocene water-level changes // Holocene. Vol.11. P. 53-63. 
Sarmaja-Korjonen K. 2003. Chydorid ephippia as indicators of environmental change - biostratigraphical evidence from two lakes in southern Finland // Holocene. Vol.13. P.691-700.

Sarmaja-Korjonen K. 2004. Chydorid ephippia as indicators of past environmental changes - a new method // Hydrobiologia. Vol.526. P.129-136.

Schilder J., Tellenbach C., Most M., Spaak P., van Hardenbroek M., Wooller M.J., Heiri O. 2015a. Experimental assessment of environmental influences on the stable isotopic composition of Daphnia pulicaria and their ephippia // Biogeosci. Discuss. Vol.12. P.25732606.

Schilder J., Tellenbach C., Möst M., Spaak P.V., Van Hardenbroek M., Wooller M.J., Heiri O. 2015b. The stable isotopic composition of Daphnia ephippia reflects changes in $\mathrm{d}^{13} \mathrm{C}$ and $\mathrm{d}^{18} \mathrm{O}$ values of food and water // Biogeosciences. Vol.12. P.3819-3830.

Sher A.V. 1997. Yedoma as a store of paleoenvironmental records in Beringida // Beringian Paleoenvironments workshop, September 20-23 Florissant, Colorado. P.140-144.

Smirnov N.N. 1992. Mesozoic Anomopoda (Crustacea) from Mongolia // Zool. J. Linn. Soc. Vol.104. P.97116.

Smirnov N.N. 2010. [Historic ecology of lake zoocenoses]. Moscow: KMK Sci. Press. 225 p. [In Russian]

Smirnov N.N. 2018. Assessment of all groups of animal remains in sediments should precede special investigation of particular groups // Invert. Zool. Vol.15. No.3. P.225-229.

Smirnov N.N., Kotov A.A. 2018. On morphological radiation of Cladocera (Crustacea) // Invert. Zool. Vol.15. No.3. P.231-248.

Strauss J., Schirrmeister L., Grosse G., Fortier D., Hugelius G., Knoblauch Ch., Romanovsky V., Schädel Ch., Schneider von Deimling Th., Schuur E.A.G., Shmelev D., Ulrich M., Veremeeva A. 2017. Deep Yedoma permafrost: A synthesis of depositional characteristics and carbon vulnerability//Earth-Sci. Rev. Vol.172. P.75-86.

Subetto D.A, Nazarova L.B., Pestryakova L.A., Syrykh L.S., Andronikov A.V., Biskaborn B., Diekmann B., Kuznetsov D.D., Sapelko T.V., Grekov I.M. 2017. Palaeolimnological studies in Russian Northern Eurasia: A review // Contemp. Probl. Ecol. Vol.4. P. 327335.

Szeroczyńska K., Zawisza E. 2005. Daphnia remains from the sediment of lake Somaslampi (NW Finnish Lapland) and Lake Wigry (NE Poland) // Stud. Quatern. Vol.22. P.55-57.

Taylor D.J., Hebert P.D.N., Colbourne J.K. 1996. Phylogenetics and evolution of the Daphnia longispina group (Crustacea) based on 12S rDNA sequence and allozyme variation // Mol. Phyl. Evol. Vol.5. P.495510.

Tomirdiaro S.V. 1996. Palaeogeography of Beringia and Arctida // C.F West (ed.). American Beginnings: The
Prehistory and Palaeoecology of Beringia. Chicago and London: University of Chicago Press. P.58-69.

Ulrich M., Wetterich S., Rudaya N., Frolova L., Schmidt J., Siegert C., Fedorov A.N., Zielhofer C. 2017. Rapid thermokarst evolution during the mid-Holocene in Central Yakutia, Russia// Holocene. Vol.27. P. 18991913.

Van Damme K., Kotov A.A. 2016. The fossil record of the Cladocera (Crustacea: Branchiopoda): Evidence and hypotheses // Earth-Sci. Rev. Vol.163. P.162-189.

Van Damme K., Sinev A.Y. 2013. Tropical Amphi-Pacific disjunctions in the Cladocera (Crustacea: Branchiopoda) // J. Limnol. Vol.72. No.S2. P.209-244.

Vandekerkhove J., Declerck S., Vanhove M., Brendonck L., Jeppesen E., Conde Porcuna J.M., De Meester L. 2004. Use of ephippial morphology to assess richness of anomopods: potentials and pitfalls // J. Limnol. Vol.63. Suppl.1. P.75-84.

Voronkov N., Troitsky V. 1907. [Survey on Glubokoye Lake] // Trudy Biostantsii Glubokoe Ozero. Vol.2. P.5-21 [in Russian].

Wappler T., Grímsson F., Wang B., Nel A., Ólafsson E., Kotov A.A., Davis S.R., Engel M.S. 2014. Before the 'Big Chill': A preliminary overview of arthropods from the middle Miocene of Iceland (Insecta, Crustacea)//Palaeogeogr. Palaeoclimat. Palaeoecol. Vol.401. P.1-12.

Wetterich S., Schirrmeister L., Nazarova L., Palagushkina O., Bobrov A., Pogosyan L., Savelieva L., Syrykh L., Matthes H., Fritz M., Gunther F., Opel T. 2018. Holocene thermokarst and pingo development in the Kolyma Lowland 1 (NE Siberia) // Permafr. Periglacial Proc. Vol.29. No.3. P.182-198.

Willerslev E., Hansen A.J., Binladen J., Brand T.B., Gilbert M.T.P., Shapiro B., Bunce M., Wiuf C., Gilichinsky D.A., Cooper A. 2003. Diverse Plant and Animal Genetic Records from Holocene and Pleistocene Sediments // Science. Vol.300. P.791-795.

Woodward C.A., Shulmeister J. 2007. Chironomid-based reconstructions of summer air temperature from lake deposits in Lyndon Stream, New Zealand spanning the MIS 3/2 transition // Quaternary Sci. Rev. Vol.26. P.142-154.

Wright H.E., Cushing E.J., Livingstone D.A. 1965. Coring devices for lake sediments // B. Kummel, D. Raup (eds.). Handbook of Paleontological Techniques. San Francisco: W.H. Freeman and Company. P.494-520.

Yan-Bin S., Di-Ying H. 2008. Extant clam shrimp egg morphology: Taxonomy and comparison with other fossil branchiopod eggs // J. Crust. Biol. Vol.28. P.352-360.

Yashina S., Gubin S., Maksimovich S., Yashina A., Gakhova E., Gilichinsky D., 2012. Regeneration of whole fertile plants from 30,000-y-old fruit tissue buried in Siberian permafrost. PNAS. Vol.109. P.4008-4013.

Zimmermann C., Lavoie C. 2001. A paleoecological analysis of a southern permafrost peatland, Charlevoix, Quebec // Can. J. Earth Sci. Vol.38. P.909-919.

Responsible editor K.G. Mikhailov 